\title{
Glucose Metabolism and Gluconic Acid Production by Acetobacter diazotrophicus
}

\author{
MARGARET M. ATTWOOD, $§$ JOHANNES P. vAN DIJKEN, AND JACK T. PRONK* \\ Department of Microbiology and Enzymology, Kluyver Laboratory of Biotechnology, Delft University of
} Technology, Julianalaan 67, 2628 BC Delft, The Netherlands

Received 27 November 1990/Accepted 19 June 1991

\begin{abstract}
Acetobacter diazotrophicus, a recently isolated nitrogen-fixing acidotolerant acetic acid bacterium, grew well in simple mineral media and exhibited high rates of gluconic acid formation. Glucose oxidation by the organism was less sensitive to low pH values than glucose oxidation by Gluconobacter oxydans. Growth and glucose oxidation were not affected by high gluconic acid concentrations. These observations indicate that $A$. diazotrophicus is an interesting organism for the industrial production of gluconic acid. The organism exhibited a high maintenance requirement $\left(\mathrm{m}_{\mathrm{S}}=1.0 \mathrm{mmol}\right.$ glucose $\left.\mathrm{h}^{-1}(\mathrm{~g} \text { dry weight)})^{-1}\right)$ during glucose-limited growth in chemostat cultures at pH 3.5. Enzyme activities in cell-free extracts suggested that glucose metabolism in $A$. diazotrophicus proceeds exclusively via the hexose monophosphate pathway: the enzymes of the Embden-Meyerhof and Entner-Doudoroff pathways could not be detected. Both the phosphorylative and direct oxidative pathways of glucose metabolism appeared to be operative. In addition to a pyridine nucleotide (strictly NAD)-dependent glucose dehydrogenase, $A$. diazotrophicus contained a dye-linked, probably pyrrolo-quinoline quinone ( $\mathrm{PQQ}$ )-dependent, glucose dehydrogenase. The latter activity seemed to be primarily responsible for gluconic acid formation.
\end{abstract}

Bacteria belonging to the genera Acetobacter and Gluconobacter are well-known for their ability to catalyse the incomplete oxidation of a wide range of organic compounds (1). Some of these bioconversions are applied in industry. For example, Gluconobacter oxydans is used on an industrial scale for the production of gluconic acid and ketogluconic acids from glucose. The physiology of $G$. oxydans, and in particular the production of gluconic acid by this organism, has been the subject of many studies.

Various vitamins and amino acids are required for optimal growth of $G$. oxydans in defined media (2). The growth requirements of the organism depend on the culture $\mathrm{pH}$ : at $\mathrm{pH}$ values below 3.5 growth does not occur in defined media (3). G. oxydans contains two enzyme activities which catalyse the oxidation of glucose to gluconic acid: a membrane-associated PQQ-dependent glucose dehydrogenase (EC 1.1.99.17, 4) and a soluble NADP. dependent glucose dehydrogenase (EC 1.1.1.47, 5). It has been demonstrated that the PQQ-linked enzyme plays a major role in gluconic acid production $(6,7)$.

Recently, a new acidotolerant Acetobacter species, called $A$. diazotrophicus, has been isolated from sugarcane roots $(8,9)$. The organism is capable of utilising molecular nitrogen as a sole source of nitrogen. In contrast to $G$. oxydans, $A$. diazotrophicus grows well in simple mineral media with ammonium salts as a source of nitrogen. The organism is also capable of growth at high sugar concentrations and produces gluconic acid from glucose (8).

The physiological characteristics of $A$. diazotrophicus described in the literature indicate that the organism may be of interest for the industrial production of gluconic acid. Therefore, our research was focused on glucose and

\footnotetext{
* Corresponding author.

$\$$ Present address: Department of Molecular Biology and Biotechnology, University of Sheffield, Sheffield S10 2TN, United Kingdom
}

gluconic acid metabolism in this organism.

\section{MATERIALS AND METHODS}

Organism and maintenance $A$. diazotrophicus LMG 7603 (ATCC 49037) was obtained from Dr. K. Kersters, Laboratory of Microbiology, Ghent State University, Ghent, Belgium. G. oxydans ATCC $621 \mathrm{H}$ was obtained from Dr. P. R. Levering, Organon Research Laboratories, Oss, the Netherlands. The organisms were maintained on a solidified medium containing per liter of demineralized water: glucose, $10 \mathrm{~g}$; Difco yeast extract, $10 \mathrm{~g} ; \mathrm{CaCO}_{3}, 20 \mathrm{~g}$; and agar, $18 \mathrm{~g}$.

Mineral medium A. diazotrophicus was grown in a mineral medium containing per liter of demineralized water: $\left(\mathrm{NH}_{4}\right)_{2} \mathrm{SO}_{4}, 3.0 \mathrm{~g} ; \mathrm{KH}_{2} \mathrm{PO}_{4}, 3.0 \mathrm{~g} ; \mathrm{MgSO}_{4} \cdot 7 \mathrm{H}_{2} \mathrm{O}$, $0.5 \mathrm{~g} ; \mathrm{Na}_{2} \mathrm{SO}_{4}, 0.75 \mathrm{~g} ; \mathrm{CaCl}_{2} \cdot 2 \mathrm{H}_{2} \mathrm{O}, 0.26 \mathrm{~g} ; \mathrm{FeSO}_{4} \cdot 7 \mathrm{H}_{2} \mathrm{O}$, $11 \mathrm{mg} ; \mathrm{ZnSO}_{4} \cdot 7 \mathrm{H}_{2} \mathrm{O}, 0.9 \mathrm{mg} ; \mathrm{MnCl}_{2} \cdot 2 \mathrm{H}_{2} \mathrm{O}, 2.0 \mathrm{mg} ; \mathrm{CoCl}_{2}$. $6 \mathrm{H}_{2} \mathrm{O}, 0.6 \mathrm{~g} ; \mathrm{CuSO}_{4} .5 \mathrm{H}_{2} \mathrm{O}, 0.6 \mathrm{mg} ; \mathrm{NaMoO}_{4}, 0.8 \mathrm{mg}$; $\mathrm{H}_{3} \mathrm{BO}_{3}, 2.0 \mathrm{mg}$; KI, $0.2 \mathrm{mg}$; EDTA, $30 \mathrm{mg}$; nitrilo-triacetic acid, $5 \mathrm{mg}$ and silicon antifoaming agent (BDH Chemicals, Poole, Dorset, UK), $25 \mu$ l. The medium was adjusted to $\mathrm{pH} 3.5$ with $1 \mathrm{M} \mathrm{H}_{2} \mathrm{SO}_{4}$ and autoclaved at $120^{\circ} \mathrm{C}$. Glucose was autoclaved separately at $110^{\circ} \mathrm{C}$. Gluconobacter oxydans was grown in glucose-limited chemostat cultures as described previously (7).

Growth conditions Batch cultures were grown in $300 \mathrm{ml}$ Erlenmeyer flasks containing $100 \mathrm{ml}$ mineral medium and incubated on a rotatory shaker at $30^{\circ} \mathrm{C}$.

Continuous cultivation was performed in Applikon laboratory fermentors with a working volume of $1 l$. The $\mathrm{pH}$ was automatically titrated with either $1 \mathrm{M} \mathrm{KOH}$ or $0.5 \mathrm{M}$ $\mathrm{H}_{2} \mathrm{SO}_{4}$. The cultures were continuously gassed with watersaturated air $\left(1 / \mathrm{min}^{-1}\right)$ and stirred at $800 \mathrm{rpm}$. Chemostat cultures were grown at a dissolved oxygen concentration higher than $75 \%$ of air saturation (i.e. $>6 \mathrm{mg} \mathrm{O}_{2} l^{-1}$ ), at $30^{\circ} \mathrm{C}$ and at $\mathrm{pH} 3.5$. 
Controlled batch cultures were performed in the same fermentors. When necessary, batch cultures were gassed with oxygen-enriched air to avoid oxygen limitation.

Culture purity was routinely checked by phase-contrast microscopy and by plating on the complex medium mentioned above.

Measurement of substrate-dependent oxygen consumption Respiration rates of cells were assayed polarographically with a Clark-type oxygen electrode (Yellow Springs Instruments Inc., Yellow Springs, Ohio, USA) at $30^{\circ} \mathrm{C}$. Cells were harvested by centrifugation $(10 \mathrm{~min}$, $10,000 \times g)$ and resuspended in either mineral medium without carbon source (pH 3.5) or in $\beta$-alanine buffer $(50 \mathrm{mM})$ containing $5 \mathrm{mM} \mathrm{MgSO}{ }_{4}$. The values presented here have been corrected for the (low) endogenous respiration rates.

Preparation of cell-free extracts Cells were harvested by centrifugation $\left(15 \mathrm{~min}, 10,000 \times \mathrm{g}, 4^{\circ} \mathrm{C}\right)$ and washed with $50 \mathrm{mM}$ potassium phosphate buffer ( $\mathrm{pH} 6.0$ ), containing $5 \mathrm{mM} \mathrm{MgCl}$. The pellet was resuspended in the same buffer to a final concentration of approximately $0.25 \mathrm{~g} \mathrm{ml}^{-1}$. Cells were disrupted by sonication at $4^{\circ} \mathrm{C}$ in an MSE $150 \mathrm{~W}$ sonifier (15 bursts of $30 \mathrm{~s}$ with intermittent cooling). Intact cells and debris were removed by centrifugation $(40,000 \times g, 20 \mathrm{~min})$. The clear supernatant, containing 5 to $11 \mathrm{mg}$ protein $\mathrm{ml}^{-1}$, was used as the cell-free extract.

Enzyme assays Spectrophotometric enzyme assays were carried out at $30^{\circ} \mathrm{C}$ with freshly prepared extracts. In all assays the reaction rates were linearly proportional to the amount of extract added. Glucose dehydrogenase (PQQ-dependent, EC 1.1.99.17), glucose dehydrogenase (NADP-dependent, EC 1.1.1.47) and hexokinase (EC 2.7.1.1) were assayed as described previously (7). Gluconate dehydrogenase (NADP-dependent, EC 1.1.99.3) was assayed according to van Schie et al. (10). Dyelinked gluconate dehydrogenase was measured with the same assay as PQQ-dependent glucose dehydrogenase except that $20 \mathrm{mM}$ gluconate was used as the substrate. Glucose 6-phosphate dehydrogenase (EC 1.1.1.49), 6-phosphogluconate dehydrogenase (EC 1.1.1.44), 6-phosphofructokinase (EC 2.7.1.4), fructose bisphosphate aldolase (EC 4.1.2.13) and the combined activity of 6-phosphogluconate dehydratase (EC 4.2.1.12) and 2-keto-3-deoxy-6-phosphogluconate (KDPG) aldolase (EC 4.1.2.14) were assayed according to van Dijken and Quayle (11).

\section{Analytical procedures}

Dry weight The dry weight of cell suspensions was determined by filtration through nitrocellulose filters (pore diameter $0.45 \mu \mathrm{m}$, Schleicher and Schüll, Dassel, FRG). After removal of the medium, the cells were washed three times with demineralised water and dried to constant weight at $70^{\circ} \mathrm{C}$.

Protein determination The protein content of cellfree extracts was determined by the method of Bradford (12). Bovine serum albumin (fatty acid free, Sigma, St. Louis, USA) was used as a standard.

Substrate determinations Glucose concentrations in media and culture supernatants were measured with the GOD-PAP method (Boehringer, Mannheim, FRG). Gluconate was assayed using Boehringer test-kit 428191 or at by HPLC on an HPX- $87 \mathrm{H}$ column $(300 \times 7.8 \mathrm{~mm}$, BioRad, USA) at room temperature. Sample were eluted with $0.01 \mathrm{~N} \mathrm{H}_{2} \mathrm{SO}_{4}$ at a flow rate of $0.6 \mathrm{ml} \mathrm{min}^{-1}$. Detection was done by means of a Waters 441 UV-detector at $210 \mathrm{~nm}$, coupled to a Waters 741 data module. Peak areas were proportional to concentrations.

\section{RESULTS AND DISCUSSION}

Growth characteristics Growth of $A$. diazotrophicus on glucose was initially studied in shake flask cultures. Growth in mineral medium occurred over the $\mathrm{pH}$ range 3.0-6.0, in accordance with the results of Gillis et al. (9). No growth was detected at $\mathrm{pH} 2.5$ and at $\mathrm{pH} 7.0$. However, some growth could be observed at $\mathrm{pH} 2.5$ in mineral medium supplemented with $0.1 \%$ yeast extract.

Growth of $A$. diazotrophicus in chemostat cultures was initially studied at $\mathrm{pH} 3.5, T=30^{\circ} \mathrm{C}$, and $D=0.10 \mathrm{~h}^{-1}$. To check whether the steady states obtained under these conditions were indeed glucose-limited, the glucose concentration in the influent medium was varied. The observed biomass yields did not differ significantly with the influent glucose concentration $\left(Y=39.0 \pm 0.3 \mathrm{~g} \mathrm{~mol}\right.$ glucose $\left.^{-1}\right)$. Electron microscopy of thin sections did not reveal any accumulation of storage polymers (results not shown). We therefore concluded that the cultures were indeed carbon and energy-limited. Low concentrations of gluconate $(0.27-0.34 \mathrm{mM})$ and 2 -ketogluconate $(0.1-0.35 \mathrm{mM})$ were detected in supernatants of chemostat cultures.

The molar growth yield of $A$. diazotrophicus in glucoselimited chemostat cultures was low compared to the growth yields of other bacteria grown aerobically on glucose (13). To investigate whether the growth yields at a dilution rate of $0.10 \mathrm{~h}^{-1}$ were influenced by maintenance requirements (14), growth of $A$. diazotrophicus was studied in glucose-limited chemostat cultures $\left(\mathrm{pH} \mathrm{3.5,T} T=30^{\circ} \mathrm{C}\right.$ ) grown at various dilution rates (Fig. 1). The maximum growth yield and the maintenance coefficient calculated from the experimental data were $51 \mathrm{~g} \mathrm{~mol}^{-1}$ and 1.0 mmol $\mathrm{h}^{-1} \mathrm{~g}^{-1}$, respectively. The maximum growth yield falls within the range of growth yields reported for aerobic bacteria. The maintenance coefficient calculated from the experimental data is rather high compared to maintenance coefficients observed with other aerobic bacteria (15). The high maintenance requirement during growth at

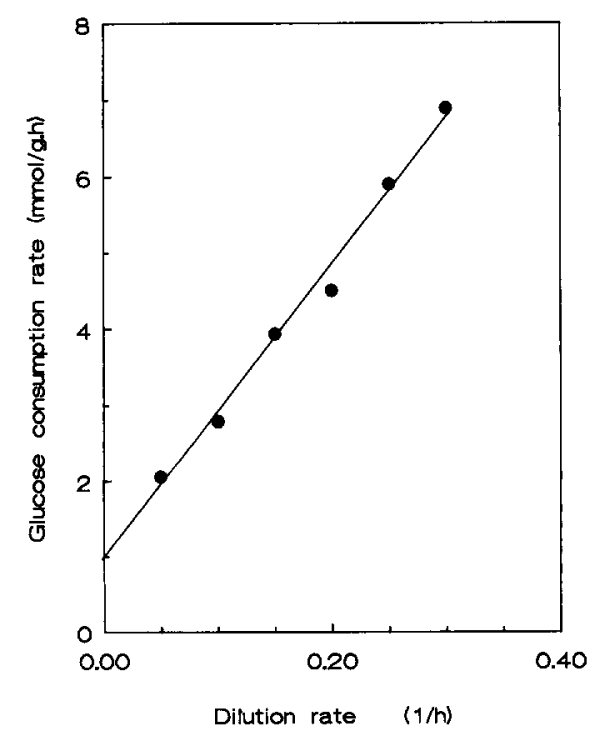

FIG. 1. Specific rates of glucose consumption by glucose-limited chemostat cultures of $A$. diazotrophicus, grown at various dilution rates. Growth conditions: $\mathrm{pH} 3.5, T=30^{\circ} \mathrm{C}, S_{\mathrm{R}}=20 \mathrm{mM}$. 
pH 3.5 may reflect an energy-dependent cytoplasmic $\mathrm{pH}$ homeostasis mechanism. Increased maintenance requirements at low pH values have also been reported for $E$. coli (16). Experiments with glucose-limited chemostat cultures of $A$. diazotrophicus grown at $\mathrm{pH}$ values above 4.0 were complicated by the formation of a viscous extracellular product, probably a polysaccharide (Attwood, unpublished results). Since maintenance energy requirements and energy stress have been implicated as important factors in the regulation of incomplete glucose oxidation by bacteria $(17,18)$, studies into the growth efficiency of $A$. diazotrophicus may be of interest for the application of the organism for gluconic acid production.

Glucose oxidation by intact cells The kinetics of glucose oxidation by intact cells of $A$. diazotrophicus were investigated by measuring the rate of glucose-dependent oxygen consumption at various glucose concentrations. Glucose oxidation by cells from a glucose-limited chemostat culture $\left(D=0.10 \mathrm{~h}^{-1}, \quad \mathrm{pH}=3.5, T=30^{\circ} \mathrm{C}\right)$ followed Michaelis-Menten kinetics (data not shown). The apparent $K_{\mathrm{S}}$ and $V_{\max }$ were $0.5 \mathrm{mM}$ and $350 \mathrm{nmol} \mathrm{O} \mathrm{min}^{-1} \mathrm{mg}^{-1}$. The $K_{\mathrm{S}}$ is comparable to the substrate saturation constants of PQQ-dependent glucose dehydrogenases from a variety of Gram-negative bacteria $(5,19,20)$, suggesting that a similar enzyme system may be involved in glucose oxidation by $A$. diazotrophicus. The observed glucose-dependent oxygen uptake rate is two- to threefold lower than oxygen uptake rates observed with $G$. oxydans grown under similar conditions $\left(D=0.10 \mathrm{~h}^{-1}, D=30^{\circ} \mathrm{C}, \mathrm{pH}=5.5 ;\right.$ (7). The cell suspensions also oxidized gluconate, with an apparent $K_{\mathrm{S}}$ of $1.4 \mathrm{mM}$ and a $V_{\max }$ of $127 \mathrm{nmol} \mathrm{O} \mathrm{min}^{-1} \mathrm{mg}^{-1}$.

During the industrial production of gluconic acid, product formation leads to a decrease of the culture $\mathrm{pH}$. The use of acidophilic or acidotolerant strains may increase the rate and efficiency of product formation. A diazotrophicus is capable of growth at low $\mathrm{pH}$ values $(9$, this paper). The $\mathrm{pH}$ range for glucose oxidation mirrored the $\mathrm{pH}$ range for growth (Fig. 2). As expected from the growth characteristics, glucose oxidation by $A$. diazotrophicus was less sensitive to low $\mathrm{pH}$ values than glucose oxidation by Gluconobacter oxydans (Fig. 2).

Enzymes of glucose metabolism The first step in the metabolism of glucose by Gram-negative bacteria may be a direct oxidation to gluconic acid (21). Alternatively, glucose may be phosphorylated prior to further oxidation. Glucose 6-phosphate formed in the latter reaction may be

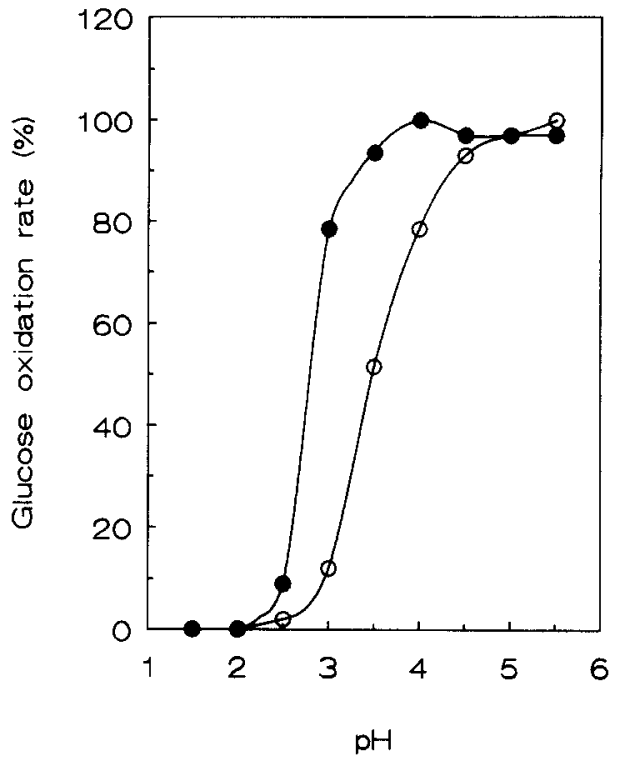

FiG. 2. Effect of pH on glucose-dependent oxygen uptake by $A$. diazotrophicus $(\bullet)$ and $G$. oxydans ATCC $621 \mathrm{H}(O)$. A. diazotrophicus was pregrown in a glucose-limited chemostat culture $\left(D=0.10 \mathrm{~h}^{-1}, T=30^{\circ} \mathrm{C}, \mathrm{pH}=3.5\right)$. G. oxydans was pregrown in a glucose-limited chemostat culture $\left(D=0.10 \mathrm{~h}^{-1}, T=30^{\circ} \mathrm{C}, \mathrm{pH}=5.5\right)$ as described previously (7). Oxidation of glucose $(20 \mathrm{mM})$ was assayed with a Clark-type oxygen electrode. $100 \%$ activity corresponds to oxygen uptake rates of $360 \mathrm{nmol} \mathrm{O} \mathrm{O}_{2} \cdot \mathrm{min}^{-1} \cdot \mathrm{mg}^{-1}$ and $750 \mathrm{nmol}$ $\mathrm{O}_{2} \cdot \mathrm{min}^{-1} \cdot \mathrm{mg}^{-1}$ for $A$. diazotrophicus and $G$. oxydans, respectively.

further metabolized via three different metabolic pathways: the Embden Meyerhof pathway or glycolysis, the pentose phosphate pathway and the Entner-Doudoroff pathway. Gluconic acid formed by the direct oxidation of glucose can be phosphorylated and subsequently metabolized via the pentose phosphate pathway or the EntnerDoudoroff pathway.

Cell-free extracts of $A$. diazotrophicus contained high activities of dye-linked glucose dehydrogenase (Table 1 ). The presence of significant concentrations of $P Q Q$ in supernatants of chemostat cultures $(10-40 \mathrm{nM}$; Dr. M. A. G. van Kleeff, pers. comm.) suggests that the dyelinked enzyme activity is due to PQQ-dependent glucose dehydrogenase (EC 1.1.99.17). This enzyme is widely distributed among aerobic, Gram-negative bacteria (22).

TABLE 1. Specific enzyme activities in cell-free extracts of $A$. diazotrophicus grown in glucose-limited chemostat cultures $\left(S_{\mathrm{R}}=20 \mathrm{mM}, T=30^{\circ} \mathrm{C}, \mathrm{pH}=3.5, D=0.10 \mathrm{~h}^{-1}\right.$ or $\left.0.30 \mathrm{~h}^{-1}\right)$

\begin{tabular}{|c|c|c|}
\hline Enzyme activity & $D=0.10 \mathrm{~h}^{-1}$ & $D=0.30 \mathrm{~h}^{-1}$ \\
\hline Glucose dehydrogenase, dye-linked & 2.6 & 1.7 \\
\hline Glucose dehydrogenase, NAD & 0.45 & 0.16 \\
\hline Glucose dehydrogenase, NADP & $<0.005$ & $<0.005$ \\
\hline Gluconate dehydrogenase, dye-linked & 0.24 & 0.88 \\
\hline Gluconate dehydrogenase, NAD & 0.26 & 0.39 \\
\hline Gluconate dehydrogenase, NADP & $<0.005$ & $<0.005$ \\
\hline Glucose 6-phosphate dehydrogenase, NAD & 0.86 & 0.48 \\
\hline Glucose 6-phosphate dehydrogenase, NADP & 0.87 & 0.54 \\
\hline 6-Phosphogluconate dehydrogenase, NAD & $<0.005$ & $<0.005$ \\
\hline 6-Phosphogluconate dehydrogenase, NADP & 2.0 & 2.0 \\
\hline Hexokinase & n.d. & 0.07 \\
\hline 6-Phosphofructokinase & $<0.005$ & $<0.005$ \\
\hline 6-Phosphogluconate dehydratase/2-keto-3-deoxy-phosphogluconate aldolase (combined activities) & $<0.005$ & $<0.005$ \\
\hline
\end{tabular}

Enzyme activities are expressed as $\mu \mathrm{mol} \mathrm{min}^{-1}$ (mg protein $)^{-1}$.

n.d.: Not determined. 


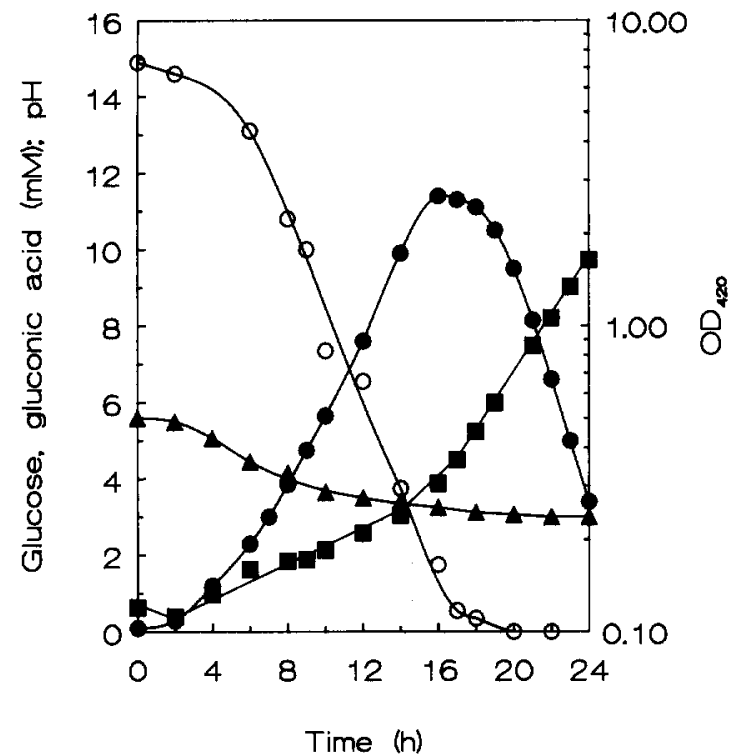

FIG. 3. Gluconic acid formation and growth of $A$, diazotrophicus on glucose in a batch culture without $\mathrm{pH}$ control. Growth conditions: $T=30^{\circ} \mathrm{C}$, initial pH 5.6. The culture was inoculated with a $20 \mathrm{ml}$ shake flask culture pregrown on mineral medium plus glucose. Symbols: $\square$, optical density at $420 \mathrm{~nm}$; $\wedge$, culture $\mathrm{pH} ; 0$, glucose concentration; $\bullet$, gluconic acid concentration.

Similar to Gluconobacter species, cell-free extracts of $A$. diazotrophicus also contained a pyridine nucleotidedependent glucose dehydrogenase (Table 1). The latter enzyme was strictly NAD-dependent. This is a remarkable difference with the enzyme from $G$. oxydans, which is strictly NADP-dependent (23). The activity of the NADdependent glucose dehydrogenase in the cell-free extracts was only $10-17 \%$ of that of the PQQ-dependent enzyme. This observation suggests that the PQQ-dependent enzyme plays a major role in the conversion of glucose to gluconic acid, as has been described for $G$. oxydans $(6,7)$. Cell-free extracts of $A$. diazotrophicus contained significant activities of hexokinase (Table 1), indicating that also the phosphorylative route of glucose metabolism may be operative in this organism.

To investigate which of the central pathways of glucose metabolism are operative in $A$. diazotrophicus, the activity of a number of key enzymes was assayed in cell-free extracts (Table 1). No activity was detected of phosphofructokinase, a key enzyme of the Embden-Meyerhof pathway of glucose metabolism. We were also unable to detect the combined activities of the key enzymes of the EntnerDoudoroff pathway, 6-phosphogluconate dehydratase and 2-keto 3-deoxygluconate aldolase. The $A$. diazotrophicus extract did not inhibit the activity of commercial preparations of the enzymes mentioned above (data not shown). Cell-free extracts of $A$. diazotrophicus did contain high activities of 6-phosphogluconate dehydrogenase. The observed enzyme activities suggest that glucose metabolism in $A$. diazotrophicus proceeds exclusively via the pentose phosphate pathway, as has been reported for $G$. oxydans (24). Radiorespirometric experiments are needed to confirm this conclusion.

In addition to the enzyme activities mentioned above, cell-free extracts of $A$. diazotrophicus also contained gluconate dehydrogenase activities (Table 1). Both dyelinked and pyridine nucleotide-dependent gluconate

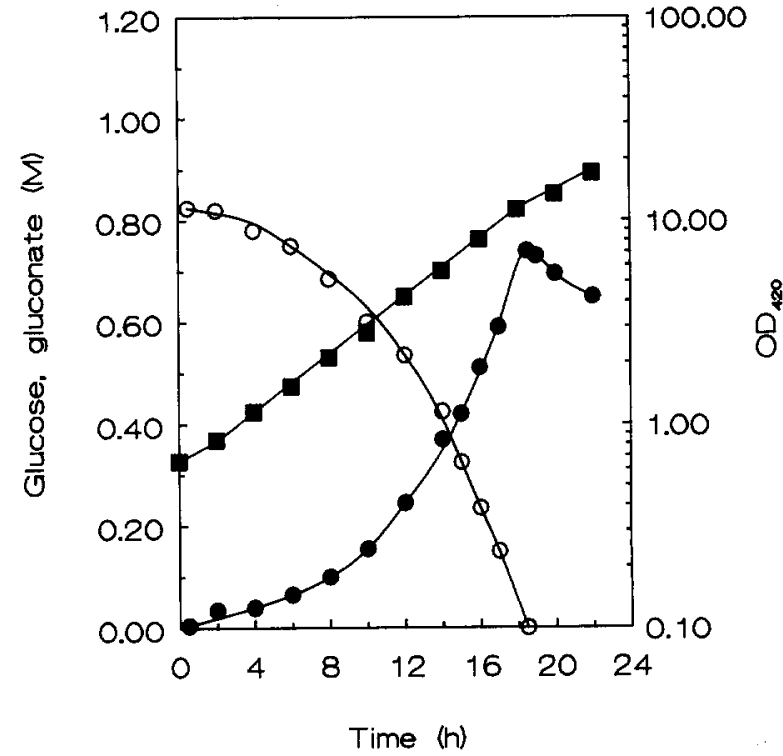

FIG. 4. Gluconic acid formation and growth of $A$, diazotrophicus in a batch culture with $\mathrm{pH}$ control $\left(T=30^{\circ} \mathrm{C}, \mathrm{pH}=3.5\right)$. Cells grown in a $1 \mathrm{l}$ glucose-limited chemostat culture $\left(D=0.10 \mathrm{~h}^{-1}\right.$, $T=30^{\circ} \mathrm{C}, \mathrm{pH} 3.5, S_{\mathrm{R}}=20 \mathrm{mM}$ ) were harvested by centrifugation and resuspended in mineral medium supplemented with $0.85 \mathrm{M}$ glucose. Symbols: $\square$, optical density at $420 \mathrm{~nm}$; $O$, glucose concentration; , gluconic acid concentration.

dehydrogenase activities were detected. The latter activity was strictly NAD-dependent, in contrast to G. oxydans, which contains both NAD- and NADP-dependent gluconate dehydrogenase activities (25).

Incomplete oxidation of glucose Preliminary experiments with shake flask cultures indicated that gluconic acid accumulated during batch growth on glucose. Growth and product formation were studied in more detail in wellaerated fermentors.

In a batch culture without $\mathrm{pH}$ control, growth of $A$. diazotrophicus on glucose followed a biphasic pattern. During the first phase, a net formation of gluconic acid occurred, until approximately $85 \%$ of the glucose was converted into gluconic acid (Fig. 3). At this point, when the glucose concentration in the culture had decreased to approximately $1 \mathrm{mM}$, a net consumption of gluconic acid set in. As a result of gluconic acid formation, the culture $\mathrm{pH}$ decreased from 5.6 to approximately 3.5 . The culture $\mathrm{pH}$ continued to decrease after all glucose had been consumed (Fig. 3). This was probably due to hydrolysis of $\delta$-gluconolactone, the initial product of microbial glucose oxidation (26).

The growth pattern observed in cultures without $\mathrm{pH}$ control differed markedly from that reported for $G$. oxydans (3). Growth of the latter organism on glucose also resulted in a rapid decrease of the culture $\mathrm{pH}$. However, in contrast to $A$. diazotrophicus, the resulting acidification of the growth medium completely inhibited gluconic acid formation and growth of $G$. oxydans (3).

According to the literature, $A$. diazotrophicus is capable of growth at high sugar concentrations $(8,9)$. When an organism is to be used to produce gluconic acid on an industrial scale, it should also be capable of glucose oxidation in the presence of high product concentrations. To check the potential of $A$. diazotrophicus for the production of gluconic acid, the organism was grown as a batch culture with 
an initial glucose concentration of $150 \mathrm{~g} l^{-1}$ (Fig. 4). The $\mathrm{pH}$ of the culture was maintained at 3.5 by automatic titration with $4 \mathrm{M} \mathrm{KOH}$. The specific growth rate in this culture remained $0.17 \mathrm{~h}^{-1}$ until all glucose was consumed. At this point approximately $85 \%$ of the substrate had been converted into gluconic acid (Fig. 4). This conversion is comparable to that observed with $G$. oxydans (7). HPLC analysis of culture supernatants also revealed the formation of significant amounts of 2-ketogluconic acid (data not shown). After the culture had been left overnight, it turned a dark brick-red, probably as a result of the formation of 2,5-diketogluconic acid (9). This phenomenon, as well as the lower oxidation capacity for glucose, is a disadvantage as compared to gluconic acid production by G. oxydans. Only after physiological and/or genetic manipulation, $A$. diazotrophicus may be a candidate for the industrial production of gluconic acid.

\section{ACKNOWLEDGMENTS}

We are indebted to Dr. K. Kersters, Ghent State University, Belgium for providing the strain of $A$. diazotrophicus used in this study. We thank Mrs. W. Batenburg-van der Vegte for performing electron microscopic studies and Dr. M. A.G. van Kleeff for performing PQQ-analyses on culture supernatants.

\section{REFERENCES}

1. Asai, T.: Acetic acid bacteria: classification and biochemical activities. University of Tokyo Press, Tokyo (1968).

2. Belly, R. T. and Claus, G. W.: Effect of amino acids on the growth of Acetobacter suboxydans. Arch. Microbiol., 83, 237245 (1972)

3. Olijve, W. and Kok, J. J.: Analysis of growth of Gluconobacter oxydans in glucose containing media. Arch. Microbiol., 121, 283-290 (1979).

4. Ameyama, M., Shinagawa, E., Matsushita, K., and Adachi, O. D-Glucose dehydrogenase of Gluconobacter suboxydans: solubilization, purification and characterization. Agric. Biol. Chem. 45, 851-861 (1981).

5. Adachi, O. and Ameyama, M.: D-Glucose dehydrogenase from Gluconobacter suboxydans. Methods Enzymol., 89, 159-163 (1982).

6. Levering, P. R. Weenk, G., Olijve, W., Dijkhuizen, L., and Harder, W.: Regulation of gluconate and ketogluconate production in Gluconobacter oxydans ATCC $621 \mathrm{H}$. Arch. Microbiol. 149, 534-539 (1988).

7. Pronk, J. T., Levering, P. R., Olijve, W., and van Dijken, J. P.: Role of NADP-dependent and quinorotein glucose dehydrogenases in gluconic acid production by Gluconobacter oxydans. Enzyme Microb. Technol., 11, 160-164 (1989).

8. Cavalcante, V. A. and Dobereiner, J.: A new acid-tolerant nitrogen-fixing bacterium associated with sugarcane. Plant and Soil, 108, 22-31 (1988).

9. Gillis, M., Kersters, K., Hoste, B., Janssens, D., Kroppenstedt, R. M., Stephan, M. P., Texeira, K. R. S., Dobereiner, J., and de Ley, J.:Acetobacter diazotrophicus sp. nov., a nitrogen-fixing acetic acid bacterium associated with sugar cane. Int. J. Syst.
Bacteriol., 39, 361-364 (1989)

10. van Schie, B. J., Rouwenhorst, R. J., van Dijken, J. P., and Kuenen, J. G.: Selection of glucose-assimilating variants of Acinetobacter calcoaceticus LMD 79.41 in chemostat cultures. Antonie van Leeuwenhoek, 55, 53-65 (1989).

11. van Dijken, J. P. and Quayle, J. R.: Fructose metabolism in four Pseudomonas species. Arch. Microbiol., 114, 281-286 (1977).

12. Bradford, M. M.: A rapid and sensitive method for the quantitation of microgram quantities of protein utilizing the principle of protein-dye binding. Anal. Biochem., 72, 248-254 (1976).

13. Linton, J. D. and Stephenson, R. J.: A preliminary study on growth yield in relation to the carbon and energy content of various organic growth substrates. FEMS Microbiol. Lett., 3, 95-98 (1978).

14. Pirt, S. J.: Principles of microbe and cell cultivation. Blackwell Scient. Publ., Oxford (1975)

15. Pronk, J. T., Meesters, P. J. W., van Dijken, J. P., Bos, P., and Kuenen, J. G.: Heterotrophic growth of Thiobacillus acidophilus in batch and chemostat cultures. Arch. Microbiol., 153, 392-398 (1990).

16. Harrison, D. E. F. and Loveless, J. E.: The effect of growth conditions on respiratory activity and growth efficiency in facultative anaerobes grown in chemostat cultures. J. Gen. Microbiol., 68, 35-43 (1971).

17. Hommes, R. W. J., van Hell, B., Postma, P.W., Neijssel, O. M., and Tempest, D. W.: The functional significance of glucose dehydrogenase in Klebsiella aerogenes. Arch. Microbiol., 143, 163-168 (1985).

18. van Schie, B. J., van Dijken, J. P., and Kuenen, J. G.: Effects of growth rate and oxygen tension on glucose dehydrogenase activity in Acinetobacter calcoaceticus LMD 79.41. Antonie van Leeuwenhoek, 55, 39-52 (1989)

19. Dokter, P., Pronk, J. T., van Schie, B. J., van Dijken, J.P. and Duine, J. A.: The in vivo and in vitro substrate specificity of quinoprotein glucose dehydrogenase from Acinetobacter calcoaceticus LMD 79.41 (1987).

20. Matsushita, K. and Ameyama, M.: D-Glucose dehydrogenase from Pseudomonas fluorescens, membrane-bound. Methods Enzymol., 89, 149-155 (1982).

21. Lessie, T. G. and Phibbs, P. V.: Alternative pathways of carbohydrate metabolism in pseudomonads. Ann. Rev. Microbiol., 38, 359-387 (1984)

22. van Schie, B. J., de Mooy, O. H., Linton, J. D., van Dijken, J. P., and Kuenen, J. G.: PQQ-dependent production of gluconic acid by Acinetobacter, Agrobacterium and Rhizobium species. J. Gen. Microbiol., 133, 867-875 (1987).

23. Adachi, O., Matsushita, K., Shinagawa, E., and Ameyama, M. Crystallization and characterization of NADP-dependent D-glucose dehydrogenase from Gluconobacter suboxydans. Agric. Biol. Chem., 44, 301-308 (1980).

24. Kitos, P. A., Wang, C. H., Mohler, B. A., King, T. E., and Cheldelin, V. H.: Glucose and gluconate dissimilation in Acetobacter suboxydans. J. Biol. Chem., 233, 1295-1298 (1958).

25. de Ley, J. and Stouthamer, A. H.: The mechanism and localization of hexonate metabolism in Acetobacter suboxydans and Acetobacter melanogenum. Biochim. Biophys. Acta, 34, 171183 (1959).

26. Jermyn, M. A.: Studies on the glucono- $\delta$-lactonase of Pseudomonas fluorescens. Biochim. Biophys. Acta, 37, 78-92 (1960). 